\title{
Value and Identification Grounds of Post-urban Life Activity Forms in Contemporary Russia
}

\author{
Grigory Donchevsky \\ Professor, PhD (Doctor of economic sciences), Head of the Chair of Management, Director of the Technological \\ Center of Regional and Municipal Activity of the Higher School of Business at Southern Federal University, 43/36 \\ 23rd Liniya, Rostov-on-Don, 344019, Russian Federation; gndonchevsky@sfedu.ru

\section{Lyudmila Klimenko} \\ Associate Professor, PhD (Candidate of sociological sciences), Associate Professor at the Chair of Management of the \\ Higher School of Business at Southern Federal University 43/36 23rd Liniya, Rostov-on-Don, 344019, Russian Federation \\ Ivklimenko@sfedu.ru
}

\section{Doi:10.5901/mjss.2015.v6n6s5p62}

\begin{abstract}
Based on the results of field sociological studies, the paper analyzes value orientations and the nature of identification of representatives of post-urban life activity forms in contemporary Russia. The authors suggest the hypothesis of new promising forms (their operating name is post-urban ones) of life and activity organization in people's communities having already emerged and been multiplying. The following signs act as leading ones in this new model of life activity: moving away from the urban binding toward new forms of involvement into the global environment; modern technological solutions - they occupy an important place in models of social and economic activity of post-urbanists; orientation to family and labor model of life support as a principal foundation of the post-urban model.Proceeding from the materials of in-depth interviews, the paper demonstrates that post-urbanization processes take place with and are supported by post-urban type values. The most important of them are the value of uniqualization succeeding the unification one, the value of modern family-based labor and daily life organization (it substitutes the value of factory- and plant-associated aloofness), the value of human-centered technological, social and daily patterns that compete wth priorities of machine production and consumption standards.
\end{abstract}

Keywords: urbanization, post-urbanization, values, identity.

\section{Introduction}

\subsection{Stage-related thoughts}

The contemporary science treats the processes objectively located in the field of post-urban problems range, as a rule, within the context of city and village relationships. Ultimately, they are "grasped" by "urbanization \& de-urbanization" pair of categories.

In relation to stages, this approach is based on the values of industrialism - within these, the city acts as a place of mass production (first of all, of profit) and a place of consumption, mass scale as well (first of all, of goods and services). Mass production (of profit and goods) is a basic value of industrialism. For this reason, it is to mass production that old forms of links and relations are resubordinated and new ones are subordinated. The city wall as a material embodiment of fear for a human's life (Donchevsky, 2010) turns into the wall surrounding the plant site - this is a material embodiment of a larve private interest, the one expressed by mass production of profit and goods as its compulsory carriers. Visually, the wall which used to dominate the city has given its place to the chimney stalk smoking over it.

Be it mentioned just as a remark, despite the city wall turning into the plant one, fear as the city's genetic basis does not disappear. On the contrary, pieces of the city wall of fear fall apart and get distributed throughout the city, they get into its each and every nook acquiring most diverse shapes - of winow grills, locks on wooden doors, doors first wrought-iron and then armor-plated, street lights, police patrols, caretakers' whistles... pepper-spray projectiles, traumatic guns, alarm buttons, video cameras... .

However, having percolated throughout the city and incarnated into most diverse embodiments, become invisible and all-permeating, fear for human life which once used to be the basic value of the medieval city has given its place to a 
new basic value - mass production (of profit and goods) that by any reckoning relies on accumulation of large quantities of population. It is only the population focused in certain points that can provide both simultaneous and joint mass production of goods and consumption thereof, mass as well. This simultaneously and jointly performing represents a curious trick: at the same time as producing and consuming the goods produced by it, the population creates what it cannot consume - the profit diffused in the goods. This profit is consumed by owners of the fenced-off factory site.

The desire to produce and consume profit made the owners to arise and spread the desire of mass consumption and, therefore, the desire and urge to pull up centuries old roots and to focus in the few individual locations (again, because production and consumption of large masses of profit cannot be thought of without concentrating the population in individual sparse points). Such focusing would yield quite rapid and quality reduction of transaction costs (Thisse, 2013; Abdel-Rahman \& Anas, 2004; Lafourdcade \& Thisse, 2011) and furnish the owners with a bonus for their succeeding in disseminating these two fundamental industrial desires. The mechanism of making profit by focusing the population in individual points ran smoothly and impeccably. It goes without saying that it was active before the idea of the "global village" (McLuhan, 2012). However, since certain times - due to cyclical nature of industrial market production - it has started to have failures: the masses of people gathered in cities proved to be larger than a city can withstand, and so, alongside with (not instead of) a stream of people leaving the village for the city (urbanization), there emerged a stream of people who left the city aiming at the village (de-urbanization). It is very important to state that when leaving the city the people said goodbye to industrialist values - coming back to the agrarian patterns of labor and life. The theoretical substantiation for both of the opposite direction processes and mechanisms acting within them originate in works of W.A. Lewis, the founding father of all literature on "dual economies" (Lewis, 1954), and M. Todaro, the author of "two-sector analysis" theory (Harris \& Todaro, 1970).

\subsection{Problem posing}

The practical dialectics of urbanization and de-urbanization in its contemporary image consists in the fact that on the one hand the quantity of urban population of the Earth exceeded that of the rural one in the first decade of the XXI century, while on the other hand the movement of downshifting has acquired mass scope (its supporters not only cut ties with the city openly, but as openly proclaim rejection of mass consumption/production ideology - the keystone of industrialism) ("The One...", n.d.).

The controversy between the two opposite phenomena was so bright and acute that it has outshined or rather diverted the researchers's view from the fact that almost at the same time with the conflict on the old industrialized values a stream of people embracing, carryng and practically (without clatter and chatter) implementing the new historical type of values - ones of post-urban nature - has emerged and started to gain momentum. Economically, the values represent that of uniqualization succeeding the unification value, that of contemporary family-based labor and daily life patterns which substitutes the value of factory and plant barracks as a extrafamilial labor appendage (even if the factory barracks first mimics a house crammed with smallish apartments and then bedroom suburbs), the value of human-centered technological patterns crowding out the mere reification ones. This list of post-urban life activity forms is not exhaustive in fact, this is just a beginning of the list (Donchevsky et al., 2014).

In the paper, we focus on the values of post-urbanism. We do not only declare their existence and word their primary appearance but we also check our theoretical assumptions against the empirical findings we have obtained during field sociological studies.

\section{Conceptual Background of the Research}

The following properties are singled out as the leading signs of post-urban life activity forms.

1) Moving away from the urban binding and new forms of involvement into the urban environment. In our opinion, the city gradually (around the middle of the XX century) started to exceed the measure of binding which is inherent in the balance of the inner binding quality with the quality of the city's involvement (inclusion) into outer environment processes having once demonstrated such a new type of inner binding of people, land, and capital that had enabled a mighty heave toward higher productivity of this and that. Having ceased to be the basis of such involvement (given its place not to organizational and settlement but to information and technological solutions) and remaining the main type of binding (going on to be perceived as one), the city has turned such binding from the liberty ensuring factor (the economical liberty, in our case) into a dismal factor of increasing dependence and oppression. Leaving the city as a place of actual residence or staying there (in this sense, they belong to one of the two big groups - the urban and the rural ones), the post-urbanists do not cut 
the binding; yet if they do, this is done not rashly and not in the heat of the moment. Their main goal is even not (and at all) the binding. The post-urbanists' attention focuses on new forms, levels and types of involvement into the outer environment, i.e. on what the city is unable to give them as such. However, it is a historical, educational, cultural, economical and social prerequisite of this for the post-urbanists (with regard to this, there is no doubt).

2) An important place in models of social and economic activity of post-urbanists is occupied by the modern technological solutions. The phenomenon of post-urban migration (both rural and intraurban) relies on the fact that when leaving the city (in fact or in name) people use the very fact of their breaking free from the pressure of urban binding in order to either essentially (up to economically significant limits) expand the use in their life activity of the modern technologies with which they dealt with in the city or to go to a new, higher technological level.

3) Orientation to family and labor model of life support. One of the research hypotheses is the assumption of rather conscious striving to destroy the type of connection that underlies the factory model on which the modern city binding is based being a driving force of post-urbanism. The sign of a mature development stage of post-urban life activity forms is restored syncretic unity of labor and family activity that is provided by the state-of-the-art technological solutions.

\section{Empirical Research Techniques}

Proceeding from the conceptual hypotheses proposed, the research tools for questionnaire surveying the representatives of Russian post-urban life activity forms were developed.

The main method of collection of the empirical material was in-depth semi-structured interviewing (llyin, 2006; Yadov, 2007; Belanovskiy, 2001; Devyatko, 1998). The selection of this empirical information collection method is explained by the fact that the goal of high-quality exploratory search is "description and interpretation of the interviewed subject's inner world elements" but "the content of an individual's inner world is sub-individual", so "the researcher digs up the individual in order to spot manifestation of the social in it" (llyin, 2006, pp. 151, 181). The method of meaning structuring by means of narrative acts as the way of interpreting the information gathered. Guided by this approach and comparing the content of narratives of the interviews collected, we can outline typical meanings which different individuals gain in typical situations occurred. Thus the social experience gained by various individuals is typized (Franzosi, 1998; Strauss \& Corbin, 2001; Divisenko, 2011; Puzanova \& Trotsuk, 2003).

The geography of questionnaire survey covered Rostov Region, Krasnodar Territory, Kaluga Region, and Moscow Region. Time of the survey is summer of 2015. A total of 12 respondents were surveyed, with 5 of them living in the city and 7 in the country - in ancestral estates, ecovillages or just in the countryside (in particular, our research touched on the settlements of ancestral estates "Rostok" in Rostov Region and "Milyonki" in Kaluga Region, "Tsitsa" ecovillage in Krasnodar Territory). Alongside with this, non-participant observation was organized in the settlements under study.

We used the following criteria for selecting the respondents. The primary criteria were: 1) a new type of activity based on post-industrial technological patterns; 2) qualification (competencies) of the carriers based on education I knowledge that were formed and translated in the urban environment; 3) syncretism of work and family (i.e. there is no separation between work and home). The secondary criteria included the following: 4) all adult family members are busy with new forms of family and labor economy; 5) the family budget receives not less than $70 \%$ of its income from implementing the new technological patterns (the mature form of post-industrial life activity form).

\section{Results of the Research}

\subsection{Empirical indicators}

In the empirical research tools, a number of conceptual blocks of questions were singled out. They are associated with the following: finding out the reasons of going away from the city binding and changing the life activity type; describing the models of business activity of post-urban life activity subjects; studying the structure of budget of urban life activity subjects and various totals thereof; revealing the social and demographic profile of post-urban type population groups; analyzing the value orientations and identity character of the representatives of post-urban life activity organization forms; describing the interpersonal communication within the settlements and the character of their interaction with the city, as well as with the representatives of the authorities; studying the life support technologies of post-urban households life and activity organization forms. 
Within the paper, let us turn our attention to describing the research findings related to value and identification grounds of post-urban life activity forms in the Russian society.

Value and motivation complex of transformation of post-urbanists' way of life was explored in our research by studying the following aspects: 1) the subjective motives of changing the previous kind / mode of work / place of residence; 2) sense-making / leading ideas of "leaving"; 3) the character of identification and value orientations of the post-urban patterns carriers.

\subsection{Motivation and sense-making ideas}

The empirical measurements conducted have shown that the leading motives for changing the way of life are the needs of self-fulfillment, freedom, creativity that were difficult to attain in conditions of the industrial employment forms. "I wanted to get freedom... It is employers who decide where to go and not you... And the life is mine. It is not so long. I'd like to not just live it but also to achieve some results, to leave a sort of imprint" (Vlad, aged 28, Rostov-on-Don). "I didn't like my previous job, it was kind of useless. For the whole day I would spend my time, my life "doing" quite useless and needed by no-one work. This made me very sad. I wanted to do something seeing the result" (Mary, aged 29, Moscow). "My previous job was mostly related to just a bright and sonorous job title... Now I do what is really interesting for me..., I'm surrounded by creative and interesting people" (Alexander, aged 32, Rostov-on-Don). "Because there has appeared a sense of freedom. Not only the freedom in time, but also the creative one" (Sergey, aged 34, gardeners' settlement). "The city has smothered me. Office is a nightmare. My husband used to call the office style, tie, shirt, and belt a strait-jacket. It is very annoying. And so is the kind of activity itself. Sitting in an office with somebody's papers and somebody's money... Seeing neither spring nor summer... And the whole life passes stupidly and absurdly" (Larisa, aged 30, Aleksandrovka village).

The idea of uniqualization, creativity, individuality, personal development can be traced in identity representations of the respondents. Our research used a simplified version of M. Kun's test "Who am I?" as a tool for studying the content characteristics of personal identity. The interviewer suggested the surveyed one: "Please, answer the question: who am I? Just give 7-8 various nouns as the answer to the question. Please answer as if you are speaking to yourself and not to another person. Give the answers in the order they occur to you, do not bother about their logic". The use of this technique is grounded and approbated in a number of studies (Klimenko \& Denisova, 2013; "Civil, ethnic and religious identities in contemporary Russia", 2006).

Among the first five identities specified by the post-urbanists, there were the content variations of the following ideas: "so to speak, a non-standard personality" (Vlad, aged 29, Rostov-on-Don), "beyond all doubts, I'm a creative person, and in particular, one who cannot get bored or depressed..." (Olga, aged 54, Elbuzd village, Rostov Region), "because my nature is but creative, constructive" (Sergey, aged 34, gardeners' settlement, Rostov Region); "... I'm a man having creative energy... That is, I don't have a task to grow 10 tons of cabbage, but rather to do something that would feed, that would be beautiful, and that would be an interesting work" (Vladislav, aged 31, "Rostok" ancestral estate).

A significant factor of reconsidering one's life strategy is also the idea of "going away from" the limitations and oppressive binding of the urbanized environment: traffic jams, poor ecology, garbage, appearance and density of location of buildings, the life rhythm, the character of communication etc. "I have tried one single time to go by car, and it took me 5 hours in the meaning of the word. I worked in the Red Square, though... Usually I took the commuter train, and it is terrible for sure - your mood gets ruined since the very morning" (Mary, 29 aged, Moscow). "There's such a crowd of people, sometimes you want to stay alone with yourself - and I cannot feel alone with myself when my neighbours are yelling" (Vlad, aged 28, Rostov-on-Don). "...Given all the "beauties" of the city life - noise, dirt, cars, exhaust gas in the air, idle groups of tipsy people" (Sergey, aged 34, gardeners' settlement). "Strange laws, vulgar ads, crazy prices, degrading language - an urban dweller is unable to change all this" (Volodar, aged 41, "Milyonki" ancestral estate). "We used to live in a block of flats. The neighbors a storey higher clatter, the ones a storey lower patter. Not a single day of peace. The city oppresses, the city destroys" (Larisa, aged 30 aged, Aleksandrovka village).

The degree of discomfort from spatial and communicative pressure of the urban environment differs depending on the respondents belonging to one of the two groups - ones living in the city or ones having left the city. The representatives of the originating post-urban patterns feel the "pressure" of the city to a smaller extent and try to bypass the existing limitations by free working schedule, an opportunity of teleworking, frequent holiday trips etc. However, in this group, the orientations to subsequent moving to suburbs are frequent too (in four of five "city-based" post-urbanists surveyed).

In a number of cases, especially among those who have moved to live in a suburb, the motive of critically perceiving the current consumption society that imposes needs and standards on the people is expressed. "We have 
grown out of the habit of independence... The choice of food, clothes, place of residence, faith is dictated to us from the outside. (...) A prestigious job, a flat with underground garage, a country cottage, another new car and already boring trips to the seaside. A lucky marriage. Trips to Venice for the wedding anniversary. Children settled in an elite school. Twenty pairs of shoes, thirty handbags. For one season. Everything keeping up with the Joneses. (...) But are these our wishes? Or is the majority of our aspirations a mere consequence of ruthless advertising by banks, producers of smartphones, flats and cars?" (Volodar, aged 41, "Milyonki" ancestral estate). Hence the motive of looking for an alternative to urban civilization is more expressed in the discourse practices of eco- and ancestral village dwellers.

Here it has to be emphasized that the outlined conceptual logics of our research implies screening out the representatives of so-called social escape (runaway) or "urban luddites" who break up all connections with the city and express active or passive confrontation with the existing urban civilization. Nevertheless, as the scientists of "Tsirkon" research group who conducted a large-scale study of Russian ecovillages in 2012 argue, "so far many ecovillages have viewed themselves solely in the opposition to civilization, they distance themselves from it, they turn in on themselves... and in this sense, they become a typical example of escapism" (Tsirkon, 2012, p. 5). On the other hand, the authors of the above research come to the conclusion that "there emerge ecovillages that are open to the world, that pursue the goal of creating something new particularly for the existing civilization, to show it the new prospects and milestones" (Tsirkon, 2012, p. 5). However, the authors do not specify what exactly prospects these are.

It is the carriers of another life organization type who are in the focus of our research - as it has been mentioned, those who are looking for new levels and forms of involvement into the socium and who are oriented to building multilevel communication with the outer socium, including the urban one. "We are not against the city, we are no anachorets or sectants. (...) The point is not in isolation from the society; this is a new social form. (...) I actively communicate with my acquaintances in the city, they often come to visit us..., I look for customers in the social networks... We openly declare our civic stance, we interact with the authorities, and we are promoting a draft legislation on ancestral estates" (Vladislav, aged 31, "Rostok" ancestral estate).

The materials of in-depth interviews identify another sense-making idea of moving (actual or desirable) to the suburb - the one consisting in hereditary / genetic connection with nature and land. "The city has been stressing me out since I was seven. Just as I remember myself, at the age of seven I got there, to a village or such, in a cottage... I've always felt great in the countryside... It is rather associated with some genetic, hereditary properties or something else. Everyone has got absolutely their own priorities. I don't like curtained windows, I like to look far into the space. When going out, I feel wonderful somewhere in the field. And if I see any houses in front of me, or an elevator, or anything else - I feel uneasy" (Lev, aged 38, Moscow and Moscow Region). "I feel the land, I love the land at genetic level... it runs bright in me. I have always been keen on land" (Olga, aged 54, Elbuzd village, Rostov Region).

\subsection{Identification and value orientations}

Life priorities of most post-urbanists surveyed are characterized by a marked value of family and family relationships. It is present both in the motives for changing the way of life and in the level of world outlook representations. "I am a very family-centered person, for me the family is always at the first place, and everything I do is for and in the name of my family" (Alexander, aged 32, Rostov-on-Don). Among the carriers of post-urban patterns, the motive of conscious parenting is frequent: "It's just I have started thinking about a child and I thought he would be better off in another place..., what I'm going to leave after myself for him, to what kind of world I'm going to invite my child. (...). You know, there is a memory of "grandfather's grapes", don't you? My memory keeps this freedom, when you can run about and go swimming in the river. This is what I want for my children" (Vladislav, aged 31, "Rostok" ancestral estate).

During the semi-structured interview, the respondents were suggested to choose three or four values that matter most for them from a list of generalized values. The respondents were suggested to range the most important for them values according to the following scale: 1) material wealth; 2) family welfare; 3) an opportunity of intellectual and creative self-fulfillment; 4) preservation of strength and health; 5) an interesting satisfying job; 6) respect of the others, public recognition; 7) an opportunity to use the democratic rights and liberties; 8) freedom from limitations of the civilization, stresses and urban pressure; 9) communication with friends; 10) other (please specify). A vast majority of the respondents marked the family welfare as one of the most significant life reference points. In the post-urbanist life priorities rating, such positions as intellectual and creative self-fulfillment and an interesting satisfying job also stand out. For the subgroup of suburban dwellers, the value of freedom from limitations of the civilization, stresses and urban pressure is more relevant while with the "city-based" post-urbanists, it is often not actualized as a priority.

Value and behavior attitudes to professional self-fulfillment closely connected to creativity, the feeling of freedom and satisfaction from work run as a common thread through all interviews of the post-urbanists. "There is some drive to 
"play Cossack" in a positive sense... Creative disobedience to some strict limits" (Sergey, aged 34, gardeners' settlement). It is important to mention that for many respondents moving from and living beyond the city (actual or expected) does not at all mean refusal from the previous profession and reorienting to agricultural works. On the contrary, the post-urbanists see more opportunities for fulfilling their professional and creative aspirations in the new conditions: "For work, I need a mood, inspiration, calm frame of mind... This was difficult to achieve earlier, when they kept distracting me by irrelevant assignments and city bustle..." (Vladislav, aged 31, "Rostok" ancestral estate).

Employing the state-of-the-art technological solutions in professional activity is the constituent parameter of organizing the life in line with the post-urban patterns. As it has been mentioned, this parameter was used as a criterion for selecting the respondents. This is why an attitude of belonging to advanced population groups is registered in the identity structure of almost all the surveyed ones. All respondents to this or that extent use the Web-based technologies in their work (they do programming, software setup, use professional software, create and service websites including ones for promoting their products and so on). Living in settlements that are quite remote from the urban environment is not an obstacle to this, either. "In the settlement, work is enough and to spare. One of the options is teleworking via the Internet, given the stable connection here, both Skylink and MTS. The connection speed allows even arranging lessons over Skype... Programing, Web design, translations - we have several people who work remotely via the Internet. One of our dwellers has a successful Internet-shop of ecogoods" (Volodar, aged 41, "Milyonki" ancestral estate). "The patterns of life in ecovillages does not contradict the age of informatization" (Veselin, aged 33, "Tsitsa" ecovillage).

A distinctive feature of representatives of the originating economic patterns is the orientation to a significant extent of autonomy - personal and psychological, professional and labor, economic and daily one. Not all respondents have it manifested equally in the three dimensions but all possess it in the first two mentioned manifestations. All post-urbanist taking part in the research determine their activities independently, the terms and schedule of their work, the customers they work with, the knowledge and tools of development they need, and so on.

The question about personal qualities that helped the respondents to change their way of life is answered by may post-urbanists as follows: it is initiative, an ability to undertake the responsibility for one's life and to not allow others to decide what one should do. "First of all, being in charge of one's own life. Another point, this goes as motivation for achieving, not one for avoiding. You have to want something and to be responsible for your wishes" (Sergey, aged 34, gardeners' settlement). Orientation to one's own forces is also manifested in answering the question about who the respondents count on when achieving their life plans. The majority of answers obtained confirm - on themselves only.

Moreover, within the eco- and ancestral villages, the carriers of post-urban practices (unlike the "urban luddites") also keep a large extent of social detachment and do not support the economic, spiritual and world outlook communality. "Everyone differs in their arrangement and patterns. Some people work in the city and keep their estates here. Others have organized their businesses here. Yet others pay short visits, they haven't settled yet. That is, this is not a commune, and we do not live up to some principles of communal earning. (...) Everyone planned and saw his dream in the "ancestral estate" template, but this vision is very different in everyone (...). Our shared topic is park area where we all take care of the land" (Vladislav, aged 31, "Rostok" ancestral estate). "Anti-authoritarian way is one of the principles of our village. There is no leader or boss. All actions are performed voluntarily, based on an agreement between all persons concerned. Nobody is obliged to be someone's subordinate, nor has anybody got a right to order someone else or impose their point of view" (Veselin, aged 33, "Tsitsa" ecovillage).

Awareness (or a mere feeling) of the inner binding that the city has set for them as their own background allows performing social transfer from typical urban forms and kinds of binding but not replacing them by other socio-cultural systems that also limit the freedom. Meanwhile, the "urban luddites" having gone away from the urban civilization form rather closed communities that are more homogeneous in economic and daily life patterns and world outlook bases.

\section{Conclusion}

Thus, the empirical material collected allows making our research hypotheses more precise in the part of determining the value and identity foundations of post-urban patterns in the contemporary Russian society. A number of sense-making ideas giving ground to the respondents' searching for new principles of organizing the life activity can be outlined: 1) critical perception of oppressing limitations of the urban civilization (rhythm of life, ecology, communication, consumer standards etc.); 2) the wish to gain freedom and self-fulfillment in labor activity; 3) spiritual motives (longing for the land, balance with the nature, looking for a meaning in life, rearing of children, continuity of generations).

The identification characteristics of a post-urbanist personality are closely connected to motivational complex of going away from the city binding. The empirical materials show that the social and achiever "I" parameters (freedom, autonomy, creativity, self-fulfillment) are competing in the identity structure of the surveyed having primordial components 
(gender and family statuses which usually are the leading ones in i-identifications).

The value and identification characteristics outlined act as a kind of world outlook basis ensuring the posturbanists' focus on performing the transfer into new economic patterns growing on the technological basis of the urban civilization. With regard to this, the orientation to labor activity including the modern technologies, blurring of boundaries between work and family, as well as openness to the socium act as a dividing ridge between the relatively small in number group of post-urban practices carriers and the group of inner migrants from the city to the countryside.

The described research is not completed by the analysis of self-consciousness and value reference points of posturbanists but it implies further identification of socio-cultural focus and social factors of post-urban life activity forms shaping, determining on this basis the possibility of new life organization forms in overcoming the social and economic inequality and conflictogenity in the socium. Moreover, the scope of the paper does not allow reflecting such important value reference points of the post-urbanists as ecologization of consciousness which is already emerging back in the depths of the urban environment and at the mass scale. The issues are the subject of our further research.

\section{Acknowledgements}

The study was performed with financial assistance of the Russian Humanitarian Science Foundation (RHSF) within "Posturban life arrangement forms in the contemporary Russia: a socio-economic analysis" (project No. 15-02-00444/15). The leader - G.N. Donchevsky, doctor of economic sciences, professor. The authors express their gratitude to colleagues A.V. Ermishina, M.A. Ponomareva, I.N. Senchenko, and all respondents for their participation in the team work on shaping of sociological research tools and exploratory studies of the empirical material that verifies the concept and hypotheses of this study.

\section{References}

Abdel-Rahman, H.M. \& Anas, A.A. (2004). Theories of systems of cities. In V. Henderson, J.F. Thisse (Eds.) Handbook of Regional and Urban Economics, Volume 4: Cities and Geography, 2293-2339. Retrieved from http:/leconpapers.repec.org/bookchap/ eeeregchp/4-52.htm

Belanovskiy. S.A. (2001). Glubokoe interviyu: uchebnoe posobie [In-depth interview: a study book]. M.: Nikkolo-Media.

Devyatko, I.F. (1998). Metody sotsiologicheskogo issledovaniya [Methods of sociological research]. Ekaterinburg: Ural university publishing house.

Divisenko, K.S. (2011). Avtobiograficheskiy narrative kak kommunikativnoe deistvie i reprezentatsiya zhiznennogo mira [(Auto) biographic narrative as a communicative action and representation of the life world]. Sotsiologicheskiy zhurnal, No. 1, 36-52.

Donchevskiy, G.N. (2010). Vozdukh goroda delaet cheloveka svobodnym [The air of the city makes one free]. Web magazine "Kapital strany". Retrieved from http://www.kapital-rus.ru/index.php/articles/article/vozduh_goroda_i_svoboda_chelovekal

Donchevskiy, G.N., Ermishina, A.V., Klimenko, L.V. (2014). Posturbanisticheskie formy zhizneustroistva v sovremennoy Rossii: postanovka problemy issledovaniya [Post-urban life arrangement forms in contemporary Russia: setting the research problem]. Aktualniye problemy razvitiya Rossii $\mathrm{i}$ ee regionov [Topical problems of development of Russia and its regions]: materials of the all-Russian scientific and practical conference. Kurgan: Tipografiya Dammi LLC.

Franzosi, R. (1998). Narrative Analysis or Why (and How) Sociologists Should Be Interested in Narrative. Annual Review of Sociology, (24), 517-554.

Grazhdanskie, etnicheskie i religiozniye identichnosti v sovremennoy Rossii [Public, ethnic and religious identities in contemporary Russia] (2006). M.: IS RAN.

Harris, J.R. \& Todaro, M.P. (1970). Migration, Unemployment and Development: A Two-Sector Analysis. The American Economic Review, 60 (1), 126-142.

Ilyin, V.I. (2006). Dramaturgiya kachestvennogo polevogo issledovaniya [Drama of a high-quality field research]. SPb.: Intersotsis.

Klimenko, L.V., Denisova, G.S. (2013). Osobennosti regional'noy identichnosti naseleniya Yuga Rossii [Particularities of regional identity of population of the South of Russia]. Sotsiologicheskie issledovaniya [Sociological research], No. 7.

Kto Nado [The One]. (2009). Nizko padshije ambitsii: manifest daunshiftera [Ambitions sinking low: a downshifter's manifest]. WEBPLANETA: jurnal dlya podklyuchennykh [a magazine for those connected]. Retrieved from http://webplanet.ru/node/15494/ print\#

Lafourdcade, M., Thisse, J.-F. (2011). New economic geography: the role of transport costs. In A. Palma, R. Lindsey, E. Quinet, R. Vickerman (Eds.) A Handbook of Transport Economics, Edward Elgar Publishing Limited, 67-96.

Lewis, W.A. (1954). Economic Development with Unlimited Supplies of Labour, The Manchester School, 22 (2) 139 - 191 , doi:10.1111/j.1467-9957.1954.tb00021.x

McLuhan, M. (1964). Foresees The Global Village. Retrieved from http://www.livinginternet.com//lii_mcluhan.htm

McLuhan, M. (2012). Voina i mir v global'noy derevne [War and peace in the global village] / Marshall McLuhan, Quentin Fiore; transl. from English by I. Letberg. M.: AST:Astrel'. 
Puzanova, Zh.V., Trotsuk, I.V. (2003). Narrativniy analiz: ponyatie ili metafora? [Narrative analysis: a notion or a metaphor?]. Sotsiologiya: 4M, №. 17, 56-82.

Strauss, A., Corbin, J. (2001). Osnovy kachestvennogo issledovaniya [Foundations of high-quality research]. M.: Editorial URSS.

Thisse, J.F. (2013). Kak transportnye izderzhki opredelyayut prostranstvennuyu strukturu ekonomicheskoy deyatel'nosti [How transport costs determine the spatial structure of economic activity]. In: Ekonomika i geografiya. Ed. A.P. Zaostrovtsev, L.E. Limonov. $\mathrm{SPb}$.: International center of social and economic research "Leontievskiy tsentr", 12-46.

Tsirkon (2012). Ekoposeleniye kak forma vnutrenney emigratsii: motivatsiya i perspektivy rasprostraneniya. Itogoviy kompleksniy analiticheskiy otchet [Ecovillage as a form of inner emigration: motivation and prospects of proliferation. Final integrated analytical report]. Retrieved from http://www.zircon.ru/upload/iblock/841/Jekoposelenija_otchet_ZIRCON_2012.pdf

Yadov, V.A. (2007). Strategiya sotsiologicheskogo issledovaniya. Opisaniye, ob'yasneniye, ponimaniye sotsialnoy real'nosti [A strategy of sociological research. Description, explanation, understanding of social reality]. Moskva: Omega-L. 